\title{
The Function of Different Chlorophylls in Photosynthesis and the Action Spectra of Separated Light Reactions
}

\author{
By A. Müller * D. C. ForK ** and H. T. WitT \\ Max-Volmer-Institut, Physikalisch-chemisches Institut der Technischen Universität Berlin \\ (Z. Naturforschg. 18 b, 142-145 [1963] ; eingegangen am 23. Oktober 1962)
}

\begin{abstract}
From action spectra of separated light reactions the function of different chlorophylls in photosynthesis have been estimated.
\end{abstract}

A reaction scheme derived from different shorttime absorption changes has already been presented $^{1-7}$. Fig. 1 shows the scheme in a simplified form. The overall process could be separated into 7 partial reactions ${ }^{5,6}$. Among others, the two light

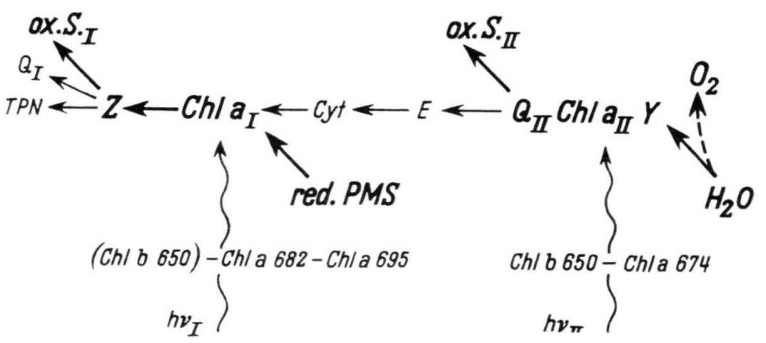

Fig. 1. Reaction scheme of the electron transport system in photosynthesis of green plants. TPN: triphosphopyridine nucleotide, Chla I and ChlaII special chlorophylls of typ a, Cyt: cytochrome, Q: plastoquinone, red. PMS: reduced phenazine methosulfate, ox. SI and ox. SII see text. Z, E and $\mathrm{Y}$ are unknown.

reactions could be isolated. In the light reaction $\mathrm{hv}_{\text {II }}$ the reaction of plastoquinone $\mathrm{Q}_{\text {II }}$ causes shorttime absorption changes with a maximum at 475 and at $515 \mathrm{~m}^{7}$ and in the light reaction $\mathrm{hv}_{\mathrm{I}}$ the reaction of $\mathrm{Chla}_{\mathrm{I}}$ causes absorption changes with a maximum at 433 and at $703 \mathrm{~m} \mu^{8,3}$.

In earlier experiments ${ }^{9}$ it was shown that in fresh chloroplasts it was possible to decouple $\mathrm{Q}_{\mathrm{II}}$ (formely symbolized by $\mathrm{X}$ and in l. c. ${ }^{1,2,6,7}$ identified as

* University of Minnesota, School of Chemistry, Division of Physical Chemistry, Minneapolis.

* Department of Plant Biology, Carnegie Institution of Washington, Stanford, California.

1 H. T. Witt, A. Müller and B. Rumberg, Nature [London] 191, 194 [1961].

2 H. T. Witt, A. Müller and B. Rumberg, Angew. Chem. 73, 507 [1961].

3 H. T. Witt, A. Müller and B. Rumberg, Nature [London] 192, 967 [1961].

${ }^{4}$ B. Rumberg, A. Müller and H. T. Witt, Nature [London] 194, 854 [1962].

5 H. T. Witt, A. Mülleer and B. Rumberg, Angew. Chem., plastoquinone) from its unknown natural reaction partner $\mathrm{E}$ by addition of oxidized $\mathrm{H}$ ill - substances, ox. $\mathrm{S}_{\text {II }}$, such as dichloro-, thymol-, and phenolindophenole, toluylene blue, thionine, and methylene blue which serve as a trap for the electrons originating in water. That ox. $\mathrm{S}_{\text {II }}$ reacts directly with $\mathrm{Q}_{\mathrm{II}}$ follows from the fact that with increasing concentration of ox. $\mathrm{S}_{\Pi \text { I }}$ the re-oxidation of $\mathrm{Q}_{\mathrm{II}}$ can be accelerated in a first order reaction by a factor of 200 and more ${ }^{9}$. Under these conditions $\mathrm{Chla}_{\mathrm{I}}$ can further work by a back flow of electrons from $Z^{\ominus}$ to $\mathrm{Chla}_{\mathrm{I}}{ }^{\oplus}$ (see ref. 4). To stop this reaction, ferricyanide was added which kept $\mathrm{Chla}_{\mathrm{I}}{ }^{\oplus}$ oxidized and non functional (no more changes at 433 and $703 \mathrm{~m} \mu$ ). This reaction mixture shows only the absorption changes at 475 and $515 \mathrm{~m} \mu$ which are caused by $\mathrm{Q}_{\mathrm{II}}$ indicating that the light reaction, $\mathrm{hv}_{\text {II }}$, has been isolated ${ }^{5,6}$ :

$$
\text { ox. } \mathrm{S}_{\mathrm{II}} \leftarrow \mathrm{Q}_{\text {II }} \mathrm{hhla}_{\mathrm{II}} \mathrm{Y} \leftarrow \mathrm{H}_{2} \mathrm{O} \text {. }
$$

Using aged chloroplasts with reduced dichlorophenol indophenol as an electron donor (ascorbic acid in excess), Vernon, Kamen and $Z_{\mathrm{AUGG}}{ }^{10}$ have shown that this system is capable of reducing $\mathrm{Hill}$ substances such as triphosphopyridine nucleotide, TPN, indigocarmine etc. in the light. We observed that this system (we used also reduced phenazine methosulfate, red. PMS, as electron donor) shows

International Edition 1, 275 [1962]; Angew. Chem. 74, 330 [1962].

${ }^{6}$ A. Müller, B. Rumberg and H. T. Witt, Proc. Royal Soc. [London], Ser. B, in the press.

7 J. Weikard, A. Müller and H. T. Witt, Z. Naturforschg. 18 b. 139 [1963].

8 В. Кок, Biochim. biophysica Acta [Amsterdam] 48, 527 [1961].

${ }^{9}$ H. T. W Wrt $_{\text {ItT }}$ and A. Müller, Z. physik. Chem., Neue Folge, 21, 1 [1959].

10 L. P. Vernon and M. D. Kamen, Arch. Biochem. Biophysics 51, 122 [1954] ; L. P. Vernon and W. S. Z ZAUGG, J. biol. Chemistry 235, 2728 [1960]. 
no absorption changes at 475 and $515 \mathrm{~m} \mu$ indicating that light reaction $h_{\text {II }}$ becomes inactive as chloroplasts age ${ }^{3}$. The changes at 475 and $515 \mathrm{~m} \mu$ (caused by $\mathrm{Q}_{\mathrm{II}}$ ) vanish also by heating fresh chloroplasts up to $50{ }^{\circ} \mathrm{C}$ and by extracting $\mathrm{Q}_{\mathrm{II}}$ from fresh chloroplasts with petroleum ether ${ }^{1,7}$. In all cases, nevertheless, the changes of Cyt and Chla still exist indicating that light reaction $\mathrm{hv}_{\mathrm{I}}$ is intact. Electrons to support a continuing reduction of $\mathrm{Chla}_{\mathrm{I}}{ }^{\oplus}$ come from, reduced PMS via Cyt. At higher concentrations $\left(\gtrsim 10^{-5} \mathrm{M}\right)$ the PMS by-passes Cyt (no more absorption changes of $\mathrm{Cyt}$ ) and reacts directly with $\mathrm{Chla}_{\mathrm{I}}{ }^{\oplus}$. The direct interaction of PMS with chlorophyll is indicated by the observation that with increasing red. PMS concentrations $\left(\gtrsim 10^{-5} \mathrm{M}\right)$ the re-reduction of $\mathrm{Chla}_{\mathrm{I}}{ }^{\oplus}$ can be accelerated in a firstorder reaction by a factor of 100 and more ${ }^{3}$.

Only under these conditions light reactions $\mathrm{h} \nu_{\mathrm{I}}$ is isolated

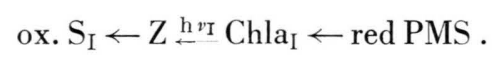

When substances accept electrons from $Z^{\ominus}$, this causes a specific behaviour of the changes at 433 and $703 \mathrm{~m} \mu$ because a back-flow of electrons from $Z^{\ominus}$ to $\mathrm{Chla}_{\mathrm{I}}{ }^{\oplus}$ is prevented (see l.c. ${ }^{4}$ and in more details l. c. ${ }^{12}$ ) By this method we have found that oxidized substances, ox. $\mathrm{S}_{\mathrm{I}}$, as indigocarmine, ferricyanide phenazine methosulfate, benzyl viologene, methyl viologene and TPN-reductase react with $\mathrm{Z}^{\ominus} 12$.

These results show that it is possible to measure the two light reactions directly by the changes at 515 and at $433 \mathrm{~m} \mu$ respectively and under conditions where they are completely separated from each other. In this communication we report the action spectra for these isolated light reactions to see directly which types of pigments are supporting them with energy by energy migration. [It has already been shown qualitatively for green plants ${ }^{1}$ that light reaction $\mathrm{hv}_{\mathrm{I}}$ (measured by the absorption changes of cytochrome) can be excited by longer wavelengths than can light reaction $\mathrm{hv}_{\text {II }}$ (measured by the absorption changes at 515 and $475 \mathrm{~m} \mu$ which are caused by $\mathrm{Q}_{\mathrm{II}}$ ) ].

The action spectrum for the $515 \mathrm{~m} \mu$ absorption change in chloroplast fragments in the presence of

11 C. S. French and I. Myers, Carnegie Inst. Wash. Yearbook 58, 323 [1959]; R. Govindjee and E. Rabinowitch, Science [Washington] 132, 355 [1960] ; Biophys. J. 1, 73 [1960] ;

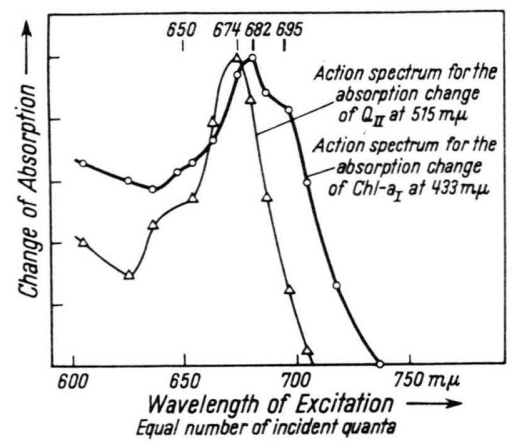

Fig. 2. The action spectra for the production of the absorption changes at 515 and $433 \mathrm{~m} \mu$ in spinach chloroplast fragments. The solution used for determining the action spectrum of the $515 \mathrm{~m} \mu$ change was $1,5 \cdot 10^{-5} \mathrm{M} / l$ dichlorophenol-indophenol, $1 \cdot 10^{-2} \mathrm{M} / l \quad \mathrm{~K}_{3} \mathrm{Fe}(\mathrm{CN})_{6}, 5 \cdot 10^{-2} \mathrm{M} / l$, tris buffer $\left(p_{\mathrm{H}} 7,2\right)$, chlorophyll concentration of $0,115 \mathrm{mg} / \mathrm{ml}$. The transmission at $674 \mathrm{~m} \mu$ of this suspension was 22 per cent. The solution used for determining the action spectrum for the $433 \mathrm{~m} \mu$ change was $9,4 \cdot 10^{-5} \mathrm{M} / \mathrm{l}$ PMS, $9,4 \cdot 10^{-3} \mathrm{M}$ sodium ascorbate, $3,8 \cdot 10^{-2} \mathrm{M} / l$ tris buffer $\left(p_{\mathrm{H}} 7,2\right)$, chlorophyll concentration of $0,150 \mathrm{mg} / \mathrm{ml}$. The transmission of this suspension at $674 \mathrm{~m} \mu$ was 17 per cent.

2,6-dichlorophenol-indophenol (DPIP) and ferricyanide is given in Fig. 2. At each wavelength measurements of the $515 \mathrm{~m} \mu$ absorption change were made as a function of increasing light intensity. Then a light intensity $\left(25 \cdot 10^{14}\right.$ quanta $\left.\mathrm{cm}^{-2} \mathrm{sec}^{-1}\right)$ was chosen such that, for each saturation curve, it fell well within the region where the $515 \mathrm{~m} \mu$ change was linear with light intensity. The absorption change produced by this constant quantum flux at warious wavelengths was then used to plot the action spectrum. The action spectrum has a peak at $674 \mathrm{~m} \iota$, a shoulder at 650 , and a far-red limit around $705 \mathrm{~m} \mu$.

From this action spectrum it follows that the light reaction, $\mathrm{hv}_{\mathrm{II}}$, is supported by light absorption by Chla -650 and Chla -674 . This result is in agreement with the Emerson effect ${ }^{11}$ (more details about the Emers on effect see 1. c. ${ }^{12}$ ).

The peak of the absorption band of the energy accepting chlorophyll engaged in the light reaction $\mathrm{hv}_{\text {II }}$ must, according to the rule of energy migration, be at a longer wavelength than the peak of the donor molecules (i.e. $>674 \mathrm{~m} \mu$ ). Absorption bands with peaks above $674 \mathrm{~m} \mu$ belong only to chlorophylls of type a. Therefore the chlorophyll in light reaction

1, 377 [1961] ; R. Govindjee, J. B. Thomas and E. Rabinowitch, Science [Washington] 132, 421 [1960].

12 H. T. Witt, A. Müller and B. Rumberg, Nature [London], in the press. 
$\mathrm{hv}_{\text {II }}$ must be a chlorophyll a $\left(\right.$ Chla $\left._{\text {II }}\right)($ s. Fig. 1) and not a chlorophyll b, as has been suggested by some authors. This has been already concluded from the Emers on effect ${ }^{11}$. The fluorescence emission of green plants has a maximum at $685 \mathrm{~m} \mu$. The chlorophyll active in fluorescence is therefore probably Chla-674.

Chla $_{\text {II }}$ has, as yet, not been seen in action by corresponding absorption changes. The reason is because the reaction of Chla II takes place in $<3 \cdot 10^{-6} \mathrm{sec}$ which follows from the reduction of $\mathrm{Q}_{\mathrm{II}}$ (causing absorption changes at 475 and $515 \mathrm{~m} \mu,<3 \cdot 10^{-6}$ sec).

Aged chlorophasts ( 7 days) which no longer exhibited changes of absorption at 475 and $515 \mathrm{~m} \mu$ were used to determine the action spectrum for the absorption change of $\mathrm{Chla}_{\mathrm{I}}$ at $433 \mathrm{~m} \mu$. PMS, reduced by excess sodium ascorbate, served as an electron source and, at the concentrations used, coupled directly to chlorophyll since no more absorption changes characteristic of cytochrome were detected. The action spectrum for the $433 \mathrm{~m} \mu$ absorption change given in Fig. 2 was determined in a manner similar to that described for the $515 \mathrm{~m} \mu$ action spectrum by measuring saturation curves at various wavelengths and selecting a light intensity $\left(100 \cdot 10^{14}\right.$ quanta $\left.\mathrm{cm}^{-2} \mathrm{sec}^{-1}\right)$ which fell within a linear region of all the saturation curves. The action spectrum for the $433 \mathrm{~m} \mu$ absorption change, in contrast to the action spectrum for the $515 \mathrm{~m} \mu$ change, remains higher at far-red wavelengths and has a limit at $\sim 735 \mathrm{~m} \mu$. The action spectrum of Fig. 2 shows a small shoulder at $\sim 650 \mathrm{~m} \mu$, a peak at 682 , and another shoulder at $695 \mathrm{~m} \mu$. This indicates that $\mathrm{Chla}_{\mathrm{I}}$ must be supplied by light which is absorbed by a Chla-682, a Chla-695 and probably also by Chlb-650 $\mathrm{m} \mu$.

Usually the chlorophyll absorption bands in green plants show only a shoulder at $650 \mathrm{~m} \mu$ reflecting chlorophyll $b$ absorption and a broad peak at $675-680 \mathrm{~m} \mu$ indicating chlorophyll-a absorption. FRENCH and co-workers ${ }^{13}$ have been able to resolve the absorption band into three components of chlorophyll-a with peaks at $673,683 \mathrm{~m} \mu$ and $695 \mathrm{~m} \mu$. In comparison with results reported

13 C. S. French, Encyclopedia of Plant Physiology, p. 252, Springer-Verlag, Berlin 1960; C. S. French, Photobiology, p. 52, Oregon State College Corvallis, Oregon 1958; J. S. Brown and C. S. French, Plant Physiol. 34, 305 [1959].

14 R. Moraw and H. T. W 29, 25 [1961]. here it can be seen that the shoulders and peaks of the action spectra correspond very well with the peaks of the absorption bands of the chlorophyll-a forms and with chlorophyll-b. From this it can be assumed that the function of Chlb-650 and Chla-673 is to support $\mathrm{Chla}_{\mathrm{II}}$ in light reaction $\mathrm{hv}_{\mathrm{II}}$ with energy and Chla-683 and Chla-695 and probably also Chlb-650 to support $\mathrm{Chla}_{\mathrm{I}}$ in light reaction $\mathrm{hv}_{\mathrm{I}}$ with energy (s. Fig. 1) *

To sum up, there exist at least seven different chlorophylls in green plants with the following function:

\begin{tabular}{|c|c|}
\hline $\begin{array}{c}\text { Energy Donor } \\
\text { (Bulk of Chlorophyll })\end{array}$ & $\begin{array}{c}\text { Energy Acceptor } \\
(\sim 1 / 1000 \text { of the Bulk })\end{array}$ \\
\hline $\begin{array}{c}\text { Chl-b-650) } \\
\text { Chl-a-682 } \\
\text { Chl-a-695 } \\
\text { Chl-b-650 } \\
\text { Chl-a-674 }\end{array}$ & $\begin{array}{c}\text { Chla }(433-703) \\
\text { in two systems * }\end{array}$ \\
\hline
\end{tabular}

(* It was shown previously ${ }^{4}$ that there exists $\mathrm{Chla}_{\mathrm{I}}$ in two different systems.)

When the chlorophylls in the bulk are separated or both light reactions are inactivated by heating to $70{ }^{\circ} \mathrm{C}^{1}$, energy migration is interrupted or prevented for photochemical consumption and the absorbed light energy should stay in the $\pi-\pi^{*}$-triplet states of these molucules. This has been directly proved ${ }^{14}$.

It is important to note that under normal conditions the absorption changes at 475 and $515 \mathrm{~m} \mu$ are biphasic ${ }^{15}$. In whole cells for instance the changes at $515 \mathrm{~m} \mu$ start in permanent light with a rapid, temperature-independent increase followed by a further, but slow and strongly temperaturedependent increase. In chloroplasts this second phase is strongly reduced but does not vanish. The second phase can be eliminated from measurement by using flashing light. When we are talking about the characteristic absorption changes of light reaction $\mathrm{hv}_{\text {II }}$ (caused by $\mathrm{Q}_{\Pi \mathrm{II}}$ ) at 475 and $515 \mathrm{~m} \mu$ we mean always the rapid changes. As yet we do not know by what reaction the second phase is produced. It may be that it is associated with longer wavelength

15 H. T. W Itt and R. Moraw, Z. physik. Chem., Neue Folge, 20, 283 [1959].

* The different types of Chl-a have the same chemical constitution but differ in their absorption bands probably by different arrangements and surroundings. 
chlorophyll components, since action spectra for the $515 \mathrm{~m} \mu$ absorption change, which we measured in permanent light and in a system where the light reactions are unseparated, have a limit at longer wavelengths than the separated system. Thus RABINowitch ${ }^{16}$ has reported action spectra for $515 \mathrm{~m} \mu$ changes in Chlorella with permanent light in unseparated systems which indicates also that a long wavelength chlorophyll may be associated with the production of changes at $515 \mathrm{~m} \mu$.

This investigation was supported by the Deut. sche Forschungsgemeinschaft.

16 E. Rabinowitch, The symposium on photochemical processes, Duke University 1962.

\title{
Trennung und Charakterisierung cytoplasmatischer Partikel aus normaler und atmungsdefekter Bädkerhefe
}

Ein Beitrag zur Frage der genetischen Kontinuität der Mitochondrien von Saccharomyces cerevisiae

\author{
Von G. Schatz und H. Tuppy
}

Aus dem Institut für Biochemie der Universität Wien

und J. Klima

Aus der medizinischen Klinik der Tierärztlichen Hochschule Wien, Elektronenmikroskopisches

Laboratorium. Vorstand: Prof. Dr. E. Gratzi

(Z. Naturforschg. 18 b, 145-153 [1963]; eingegangen am 6. September 1962)

\begin{abstract}
-Um die Frage nach dem Vorliegen von Mitochondrien in der atmungsdefekten, cytoplasmatischen „petite“-Mutante von Saccharomyces cerevisiae zu klären, wurden aus schonend hergestellten Homogenaten normaler Bäckerhefe und der ,petite“-Mutante die in der Zentrifuge zwischen 1500 und $26300 \mathrm{~g}$ sedimentierenden cytoplasmatischen Partikel isoliert und im Saccharose-Dichtegradienten fraktioniert. Die erhaltenen Rohsedimente sowie die einzelnen Fraktionen wurden enzymatisch und elektronenmikroskopisch untersucht. Dichtegradienten-Gleichgewichtszentrifugierung des Sedimentes aus normaler Hefe ergab bei schonendem Homogenisieren zwei Banden, deren spezifisch leichtere (Dichte $1,19 \mathrm{~g} \cdot \mathrm{cm}^{-3}$ ) die Mitochondrien des Rohsedimentes in gereinigter Form enthielt. Die spezifisch schwerere Bande (Dichte $1,23 \mathrm{~g} \cdot \mathrm{cm}^{-3}$ ) bestand aus offenen oder geschlossenen Doppelmembranen, die eine sehr aktive, $\mathrm{Mg}^{2}{ }^{\oplus}$-stimulierte ATPase enthielten, jedoch frei von typisch mitochondralen und mikrosomalen Enzymen waren; diese Membranen sind vermutlich Trümmer des endoplasmatischen Retikulums der Hefezelle. Nach länger dauernder Homogenisierung der Zellen konnte noch eine dritte, meist sehr schwache, Bande beobachtet werden (Dichte $1,14 \mathrm{~g}^{\cdot} \mathrm{cm}^{-3}$ ), die wahrscheinlich aus Mitochondrienfragmenten besteht. Die Auftrennung des Sedimentes der „petite“-Mutante ergab ein prinzipiell gleiches Bild. Auch bei der Mutante zeigten die Atmungsenzyme Succinatdehydrogenase und DPNH-Cytochrom-c-Reduktase eine charakteristische mitochondrale Verteilung im Gradienten (Dichte $1,19 \mathrm{~g} \cdot \mathrm{cm}^{-3}$ ); sie sind also an Mitochondrien gebunden. Von den getesteten Enzymen fehlte lediglich Cytochromoxydase. Die Menge der Mitochondrienfragmente sowie der spezifisch schwereren Membranfraktion (Dichte $1,23 \mathrm{~g} \cdot \mathrm{cm}^{-3}$ ) war meist stark vermehrt.

Der Nachweis von Mitochondrien auch in der „petite“-Mutante ist mit jenen bisherigen Vorstellungen über diese erbliche Veränderung unvereinbar, die die Abwesenheit von Mitochondrien in der Mutante voraussetzen. Die bei der „petite“-Mutation ausfallenden extrachromosomalen Faktoren mit genetischer Kontinuität können also nicht mit den Mitochondrien identisch sein.
\end{abstract}

In Hefekulturen treten spontan ,petite“-Mutanten auf, die auf bestimmten Nährböden Zwergkolonien bilden ${ }^{1}$. Die Häufigkeit ihres Auftretens liegt in der Größenordnung von $1 \%$, kann jedoch durch Acridinfarbstoffe wie Acriflavin auf nahezu 100\% erhöht werden ${ }^{2}$. Nach den Untersuchungen von

1 B. Ephrussi, Naturwissenschaften 43, 505 [1956].

2 B. Ephrussi, H. Hottinguer u. A. M. Chimenes, Ann. Inst. Pasteur 76, 351 [1949].
Ephrussi, Slonimski und Mitarbb. ${ }^{3-5}$ handelt es sich hier um eine irreversible Mutation, deren besondere Eigenschaften nicht nach $\mathrm{Mendelschen}$ Gesetzen weitervererbt werden, sondern die durch Veränderung oder Verlust eines extrachromosomalen, höchstwahrscheinlich cytoplasmatischen Faktors

3 B. Ephrussi u. H. Hottinguer, Cold Spring Harbor Sympos. quantitat. Biol. 16, 75 [1951].

4 J. Tavlitzki, Ann. Inst. Pasteur 76, 497 [1949].

5 P. P. Slonimski, Ann. Inst. Pasteur 76, 510 [1949]. 